\title{
CHANGE MANAGEMENT FOR THE POST COVID-19 SCENARIO: APPLICATION OF ELOS R (ENERGY LOSS RISK) TOOL
}

\author{
Jade Spinola Ávilaa, Salvador Ávila Filho ${ }^{a}$, Reinaldo Coelho Mirréb \\ a Federal University of Bahia, Brazil, \\ b SENAI CIMATEC University Center
}

\begin{abstract}
The world is currently going through a process of successive natural and social degradation due to the growing emission of greenhouse gases and a global health crisis caused by the COVID-19 pandemic, requiring good change management to ensure the safety of public health and economic recovery. The objective of this work is to present ELOS R as an alternative to develop indicators and assist in management making processes more resilient. The object of study, supply chain evaluation and, finally, the application of the tool in the $\mathrm{H}_{2}$ production chain are determined. There were opportunities to reduce $\mathrm{CO}_{2}$ and energy emissions associated with changing behavior and operational control in relation to new projects and facilities in operation.
\end{abstract}

Keywords: COVID-19; ELOS R; energy; industry; behavior

\section{GESTÃO DE MUDANÇA PARA O PÓS COVID-19: APLICAÇÃO DA FERRAMENTA ELOS R (ENERGY LOSS RISK)}

Resumo: Atualmente o mundo está passando por um processo de degradação natural e social sucessiva devido à crescente emissão de gases do efeito estufa e uma crise sanitária global provocada pela pandemia do COVID-19, exigindo uma boa gestão de mudanças para garantir a segurança da saúde pública e recuperação da economia. O objetivo deste trabalho é apresentar o ELOS R como alternativa para desenvolver indicadores e auxiliar na gestão tornando os processos mais resilientes. É determinado o objeto de estudo, avaliação da cadeia de suprimento e, por último, a aplicação da ferramenta na cadeia produtiva de $\mathrm{H}_{2}$. Verificou-se as oportunidades de diminuição de emissão de $\mathrm{CO}_{2}$ e energia associada à mudança de comportamento e controle operacional em relação a novos projetos e facilidades em operação.

Palavras-chave: COVID-19; ELOS R; energia; industria; comportamento 


\section{INTRODUCTION}

Currently the world is going through a process of successive natural and social degradation. The increasing $\mathrm{CO}_{2}$ emission has the consequence of the greenhouse effect, which is represented by climatic changes, such as rainfall changes, sea level rise and changes in biota and reduced quality of life [1]. Associated with the problem of $\mathrm{CO}_{2}$ emissions into the atmosphere, there are also social, political and economic crisis caused by COVID-19. Therefore, despite programs to reduce carbon emissions, is necessary a change in human-social behavior to improve post-COVID-19 scenario.

Taleb, [2], claims that our planet is saturated with a large population living in the same environment and that there is no care to maintain the global balance, may arise the event called Black Swan can arise. This big impact event is unknown and this can make it difficult the treatment of the crisis. Maybe we can consider that the COVID-19 pandemic is a Black Swan, an event that caused an economic and social stop of planet in order to meet the strategy of preventing the contamination of the virus through the displacement of people.

The decisions making in unexpected global crisis can be uncertain and cause more serious impacts. The pandemic can be seen as an event in which economic and political structures are challenged and remodeled for the possibilities of to redefine the ecological burdens created by industrial activities [3]. With the scenario of a momentary stop in the emission of $\mathrm{CO}_{2}$ and polluting gases, was possible to increase cleaned the air, try to close the hole in the ozone layer and regressed environmental degradation [4]. Aerial photographs can show emissions before and during the pandemic and, at the same time, not usual natural phenomena, such as swarms of locusts [5], aerial dust moving from Africa to the USA [6], reappearance of animal species [7], cyclones in unexpected regions [8], among other events.

The impacts of the pandemic caused by COVID-19 severely affect the economy and society and can increase the level of degradation on the planet. The airlines partially closed; automotive industry markets and production plummeted; shops, restaurants and bars closed; sporting events have been postponed or canceled; universities and schools have adopted online learning by creating a gap in the learning process; and public transport has been radically altered [3].

In relation to oil supply, the Organization of Petroleum Exporting Countries (OPEC) and its allies have pledged a 10\% reduction in crude oil production to raise prices that were below $\$ 25$ a barrel [3], trying not to cause a global breakdown in no renewable energy industry. Another important factor is the decrease in the mobility of individuals, causing a decrease in the distribution speed of global products and an increase in the need for local solutions. People are using the social media such as a new living environment in the commercial and leisure segments, providing manipulating the economy and society through fake news [9].

The uncertainty in the decisions during the pandemic can generates consequences, bringing, for the managers, the challenge of transforming the economic and social environment to avoid possible behaviors that can cause future crisis. The scenario of crisis consequence should requires new worker behavior, management tools and technologies. Leadership must be reorganized for a challenging scenario seeking to manage changes and make complex decisions in the different segments. 
The new tools must identify organizational threats to the stability of processes, from the investigation of behavior at the workplace, the management of systems reliability, the control of the supply chain and the control of equipment to avoid energy losses. All possible solutions can be developed in existing industries and new projects can be developed.

Ávila et al. [10, 11], proposes a tool that evaluates micro processes (jobs and units in the industry) at the same level of importance in relation to macro processes (local and global supply chains) to avoid energy losses in the operation of the units current. Post-crisis behavior is studied based on social relationships and the technical operational culture installed on the workstation, which are based on the analysis of the operator discourse [12]. The control of this behavior can be done through indicators of good practices [13]. The energy losses can be analyzed by critical equipment furnaces and cooling towers, industrial units - oil refinery and a group of companies in the same industrial segment - chemical industry.

The focus of this paper is to discuss the scenario of post-crisis behavior and the possible reduction of energy losses in the functioning of cities and, mainly, industry through to the application of the ELOS R tool. The discussion is based on the industrial environment and consumption of energy in manufactures and small companies. Is evaluated how to control operations to reduce energy consumption, which directly or indirectly reduces the emission of carbon dioxide and how to adopt a good behavior. In sequence wil be presented the ELOS R tool and the opportunities for avoid energy loss already evaluated in others works. Will be discussed, also, the steps before the ELOS R tool use and an application exercise of the proposed steps for the hydrogen production supply chain, and finally, the conclusions.

\section{THE TOOL: ENERGY LOSS RISK (ELOS R)}

ELOS R (Energy Loss Risk) $[10,11]$ is a tool for analyzing dynamic behavior in social relationships and its implications for energy loss and unsafe behavior in the operational routine. Identifies possible sources of stress, types of leadership in management, and indicates tools for qualitative and quantitative analysis. These analyzes identify the impacts of losses related to climate change and the dynamic culture of society in the processes.

Using the tool, indicators are provided in the areas of energy and security, to identify micro and macro processes in the supply chain and to make organizations and processes more resilient in relation to threats. The tool addresses important concepts within an industrial or urban supply chain. The application of this tool allows the discussion of some concepts such as, local and global views of processes and reliability, sociotechnical relationships in micro and macro processes, routine performance analysis and loss of processes involving organizational culture, behavior and human factors.

Basic industries transform raw materials into finished products that are distributed and sent to final consumers. The supply chain must adopt behaviors that avoid losses of processes, energy and time, in addition to avoiding accidents and consequent environmental impacts, maintaining the image of the company sustainable and with continuous performance within the established standards. Therefore, evaluating a supply chain is to understand how organizations are interrelated to 
produce a product or service. Figure 1 presents a field of opportunities to use the ELOS $\mathrm{R}$ tool in micro processes in industry and society that can be explored, assisting decision making in the post-pandemic scenario.

Figure 1. Grid ELOS R [10]

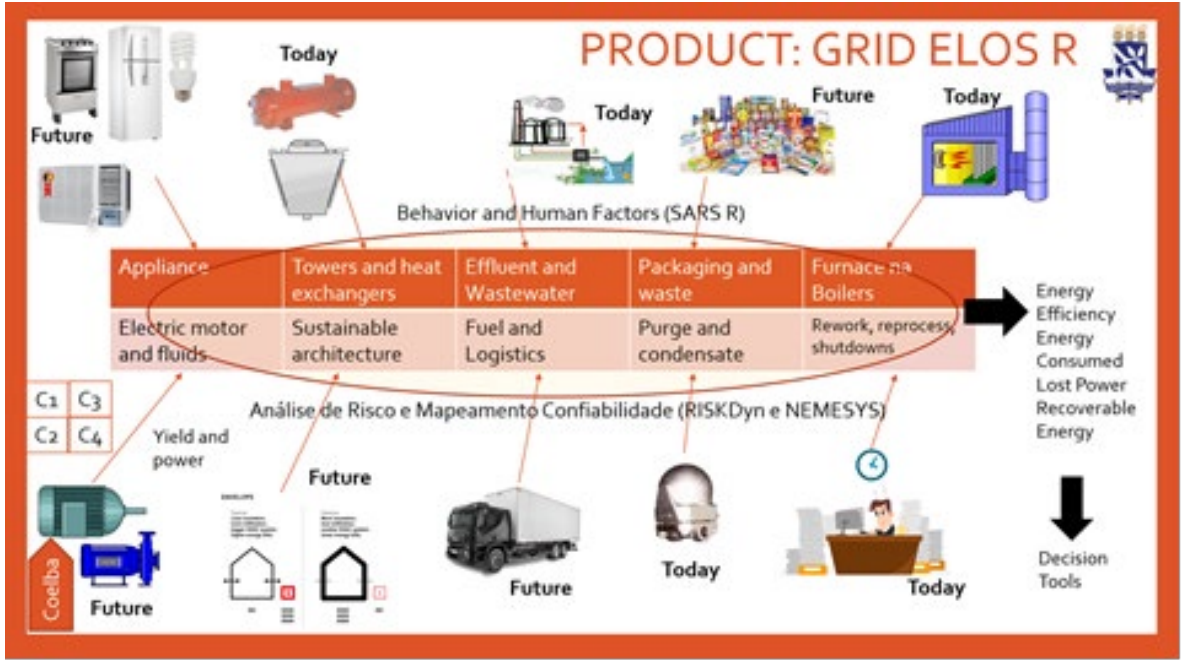

This figure highlights the various segments where you may experience loss of energy and need to change behavior. There are current and future possibilities for risk and reliability analysis of processes and equipment that must be evaluated.

\subsection{Opportunities for Energy Loss}

The Table 1 presents a risk matrix and source of energy loss in various equipment and processes. After analyzing the process and using the ELOS R tool, changes are proposed in the management and routine to recover lost energy.

Table 1. Risk matrix and source of energy loss [10]

\begin{tabular}{|c|c|c|c|c|c|}
\hline $\begin{array}{l}\text { Energy Loss } \\
\text { (ELOS) }\end{array}$ & Equipment & $\begin{array}{l}\text { Managerial } \\
\text { decision }\end{array}$ & Routine & $\begin{array}{l}\text { ELOS } \\
(\mathrm{GJ} / \mathrm{h})\end{array}$ & $\begin{array}{c}\text { Energy } \\
\text { Rec. } \\
(\%)\end{array}$ \\
\hline $\begin{array}{c}10 \% \text { recycle } \\
\text { flow not useful; } \\
5 \% \text { air } \\
\text { recirculating } \\
\text { fan }\end{array}$ & $\begin{array}{l}\text { Cooling } \\
\text { Tower }\end{array}$ & $\begin{array}{l}\text { Attention to } \\
\text { water and } \\
\text { energy, } \\
\text { maintenance }\end{array}$ & $\begin{array}{l}\text { Blowdown, } \\
\text { treatment, } \\
\text { cycle }\end{array}$ & 15 & 30 \\
\hline $\begin{array}{l}\text { Intermittent or } \\
\text { continuous } \\
\text { operation in } \\
\text { bad pattern }\end{array}$ & No Invest. & $\begin{array}{l}\text { Time to think, } \\
\text { force task }\end{array}$ & $\begin{array}{l}\text { Normalization } \\
\text { of deviation }\end{array}$ & 3 & 80 \\
\hline
\end{tabular}




\begin{tabular}{|c|c|c|c|c|c|}
\hline $\begin{array}{l}\text { Wrong } \\
\text { decision of } \\
\text { production } \\
\text { control }\end{array}$ & $\begin{array}{c}\text { Plant Invest. } \\
\text { better } \\
\text { parameter }\end{array}$ & $\begin{array}{c}\text { Campaign } \\
\text { wrong setup }\end{array}$ & $\begin{array}{l}\text { Normalization } \\
\text { of deviation }\end{array}$ & 2 & 100 \\
\hline $\begin{array}{c}\text { Groups of } \\
\text { motors out of } \\
\text { best yields in } \\
\text { operation point } \\
20 \%\end{array}$ & Motor-pump & $\begin{array}{c}\text { Increment of } \\
\text { charge in } \\
\text { process }\end{array}$ & $\begin{array}{c}\text { More charge, } \\
\text { more } \\
\text { amperage }\end{array}$ & 2 & 50 \\
\hline $\begin{array}{l}\text { Furnace and } \\
\text { boiler heat } \\
\text { losses by hot } \\
\text { wall, } 0,3 \% \text { total } \\
\text { energy losses }\end{array}$ & $\begin{array}{c}\text { Furnace and } \\
\text { Boiler }\end{array}$ & $\begin{array}{c}\text { Low } \\
\text { investment or } \\
\text { undue } \\
\text { quotation to } \\
\text { maintenance }\end{array}$ & $\begin{array}{l}\text { No Audit in } \\
\text { energy losses }\end{array}$ & 1,5 & 70 \\
\hline $\begin{array}{c}\text { Low } \\
\text { performance of } \\
\text { plant due to } \\
\text { wrong } \\
\text { decisions, } \\
\text { equivalent } \\
\text { shutdown, } \\
0,5 \%\end{array}$ & $\begin{array}{c}\text { Critical } \\
\text { equipment, } \\
\text { plant, } \\
\text { process }\end{array}$ & $\begin{array}{l}\text { Low } \\
\text { Investment in } \\
\text { root cause to } \\
\text { avoid process } \\
\text { loss }\end{array}$ & $\begin{array}{l}\text { No operation } \\
\text { tests to find } \\
\text { cause }\end{array}$ & 0,2 & 90 \\
\hline $\begin{array}{c}\text { Draining } \\
\text { operation of } \\
\text { cooling tower } \\
\& \text { boiler, } \\
\text { abnormal } \\
\text { purge, } 0,001 \%\end{array}$ & $\begin{array}{c}\text { Abnormal } \\
\text { blowdown } \\
\text { due process }\end{array}$ & $\begin{array}{l}\text { Low } \\
\text { Investment in } \\
\text { root cause to } \\
\text { avoid process } \\
\text { loss }\end{array}$ & $\begin{array}{l}\text { Attention and } \\
\text { commitment }\end{array}$ & 0,1 & 80 \\
\hline
\end{tabular}

This adapted table [10] presents a risk matrix containing the sources of energy losses, the equipment evaluated, the management decisions and the necessary changes in the routine within a refining industry. It seems that many changes are related to human factors, where behavior change is necessary, this behavior can be amplified in a post-COVID-19 scenario and, therefore, must be inhibited.

The industry segment contributes more than $33 \%$ to $\mathrm{CO}_{2}$ emissions and can be reduced through energy integration in projects, intensification of the process and better efficiency of utilities in the routine. In this context, if the global industry reduces at least $25 \%$ of the thermal energy lost, $20 \%$ of the steam losses, and if the fuel oil is changed to renewable by $33.8 \%$, the greenhouse effect decreases by $33 \%$. The projected results in the reduction of $\mathrm{CO}_{2}$ emissions in the industry are added up and almost exceed the target of 21.6GTY. The segments of society can prepare programs and transform the exercise into practice, providing a better quality of life for the terrestrial population [14]. In this context, it is proposed to use the ELOS R tool. 


\section{METHODOLOGY}

The steps necessary until the ELOS R tool application is proposed by the block diagram of Figure 2.

Figure 2. Step for application

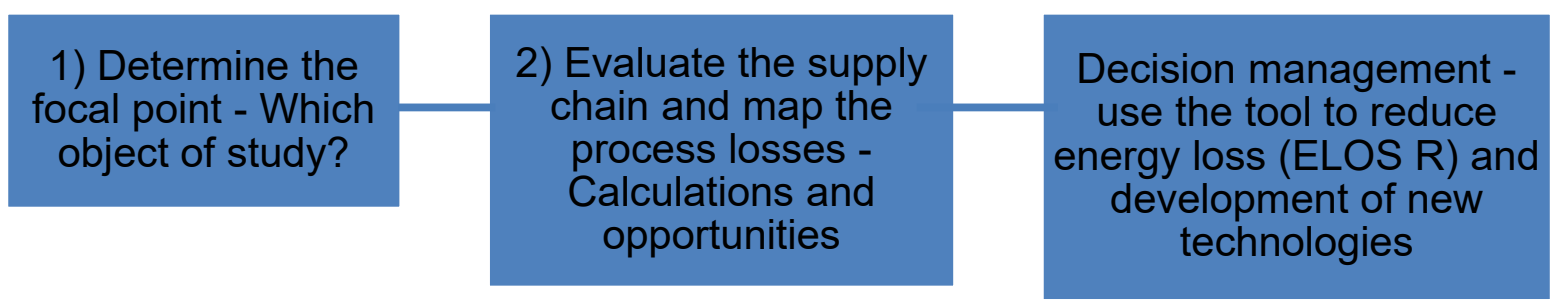

In the first stage, the main object of study is determined, which industry, process or equipment will be analyzed. After this stage, the supply chain of the study focus is evaluated, at that moment the energy losses are mapped based on calculations and opportunities evaluation. In the last step, management should apply the ELOS R tool and verify the opportunity to develop new projects and technologies that contribute to reducing energy loss and $\mathrm{CO}_{2}$ emissions.

\section{RESULTS AND DISCUSSION}

Based on this approach, it is possible to make more assertive decisions in different sectors of society and make micro processes and macro processes within the supply chain more profitable and safer.

\subsection{Application of the Proposed Steps for the Hydrogen Production Supply Chain}

Currently, 120 million tons of hydrogen $\left(\mathrm{H}_{2}\right)$ are produced per year [15], of which about $95 \%$ of all this hydrogen is generated from natural gas, via steam reforming of methane (SMR) [16]. The SMR process is responsible for considerable carbon dioxide emissions, having an emission factor of $9.5 \mathrm{~kg}$ of $\mathrm{CO}_{2}$ per $\mathrm{kg}$ of $\mathrm{H}_{2}$ [17]. When the steam reform process is associated with a carbon capture and storage system, this factor can be reduced to $1.8 \mathrm{kgCO}_{2} / \mathrm{kgH}_{2}$, with the production cost of these plants being 1.72.8USD/kgH 2 [15]. The production of $\mathrm{H}_{2}$ by renewable energies such as wind and solar, through water electrolysis, has a high cost, 3.0-7.5USD/kgH 2 [15].

1) Study Object: Production of hydrogen $\left(\mathrm{H}_{2}\right)$ via steam reforming of methane (SMR).

2) Supply chain assessment and process loss mapping: The supply chain involves methane production and desulfurization, $\mathrm{H}_{2}$ production, storage, transport and use. The following points must be detailed in order to make a quantitative and qualitative analysis of the processes and energy losses. 
- Assess the energy consumption of production;

- Cost of transportation and storage;

- $\mathrm{CO}_{2}$ emission in production;

- Analysis of operational control;

- Human behavior;

3) Decision management: With the supply chain mapping and the calculation of losses and opportunities, alternatives should be evaluated to reduce the impacts of $\mathrm{H} 2$ production via SMR. The ELOS R tool can be applied to reduce the energy loss of the process or to develop new projects, such as carbon capture or substitute the production method that uses renewable energy sources.

\section{CONCLUSIONS}

In view of the post-COVID-19 scenario and analysis of existing process losses, there is a need for good change management and paradigm breaking. The losses are not only related to equipment and processes, but also to reliability and human behavior. These factors are directly related to the types of leadership and decision making in crisis. In this context, there is a need to change the pattern of human behavior and, in the case of this work, the proposed technological tool, ELOS R, is of great use to increase the performance of activities. The application of this tool is advantageous due to the possibility of mapping energy losses, and identifying opportunities for improvements and behavioral change in post-COVID-19 within the industrial environment, but still need real case application after crisis post pandemic to validated this study.

\section{REFERENCES}

${ }^{1}$ Allan, J., Donovan, C., Ekins, P., Gambhir, A., Hepburn, C., Reay, D., Zenghelis, D. (2020). A net-zero emissions economic recovery from COVID-19. Smith School Working Paper No. 20-01, 4214(20-01), 0-22. Retrieved from https://www.smithschool.ox.ac.uk/publications/wpapers/workingpaper20-01.pdf

${ }^{2}$ Taleb, Nassim Nicholas. O cisne Negro. Leya, 2017.

${ }^{3}$ Wells, P., Abouarghoub, W., Pettit, S., \& Beresford, A. (2020). A socio-technical transitions perspective for assessing future sustainability following the COVID-19 pandemic. Sustainability: Science, Practice, and Policy, 16(1), 29-36. https://doi.org/10.1080/15487733.2020.1763002

${ }^{4}$ Kim, Allen. Maior 'buraco' já registrado na camada de ozônio se fecha no Ártico. CNN Brasil. 29 de abril de 2020. Disponível em: < https://www.cnnbrasil.com.br/internacional/2020/04/29/maior-buraco-ja-registradona-camada-de-ozonio-se-fecha-no-artico> Acesso em: 10 de agosto de 2020.

${ }^{5}$ Otoboni, Jéssica. Nuvem de gafanhotos invade cidades na Argentina e assusta agricultores do Brasil. CNN Brasil. São Paulo, 23 de junho de 2020. Disponível em: 
<https://www.cnnbrasil.com.br/tecnologia/2020/06/23/nuvem-de-gafanhotos-assustaagricultores-do-brasil>Acesso em: 10 de agosto de 2020.

${ }^{6} \mathrm{O}$ que é a 'nuvem de poeira Godzilla', que viaja $10 \mathrm{mil} \mathrm{km}$ do Saara para as Américas. BBC. 23 de junho de 2020. Disponível em: < https://www.bbc.com/portuguese/geral53153779>. Acesso em: 10 de agosto de 2020.

${ }^{7}$ Scorsin, Ana Paula. Isolamento social ajuda na recuperação ambiental. EcoDebate, ISSN 2446-9394, 01 de abril de 2020. Disponível em: < https://www.ecodebate.com.br/2020/04/01/animais-silvestres-em-cidades-canaiscristalinos-e-ar-limpido-confira-o-impacto-do-isolamento-social-na-natureza/>. Acesso em: 10 de agosto de 2020.

${ }^{8}$ Novo ciclone com ventos de até $100 \mathrm{~km} / \mathrm{h}$ pode atingir Sul do Brasil em até 48h. CNN Brasil. 06 de julho de 2020. Disponível em: < https://www.cnnbrasil.com.br/nacional/2020/07/06/novo-ciclone-com-ventos-de-ate100-km-h-pode-atingir-sul-do-brasil-em-ate-48h>. Acesso em: 10 de agosto de 2020.

9 Twitter is 'interfering' in US election, 'stifling' free speech, alleges Trump. The Economic Times. 27 de maio de 2020. Disponível em: < https://economictimes.indiatimes.com/news/international/world-news/twitter-isinterfering-in-us-election-stifling-free-speech-allegestrump/articleshow/76025295.cms>. Acesso em: 10 de agosto de 2020.

10 Ávila Filho, S., Cerqueira, I., \& Ávila, J. S. (2018). Energy Loss Risk (ELOS R) in Supply Chain, micro \& macro processes. Advances in Intelligent Systems and Computing, 793, 354-366. https://doi.org/10.1007/978-3-319-94196-7_33

11 Ávila Filho, S., Cerqueira, I., \& Ávila, J. S. (2019). Energy Loss Risk (ELOS R) in Supply Chain, Micro-processes to Decrease Greenhouse Gas Emissions. 14th Global Congresso n Process Safety. Orlando, Florida.

12 . Ávila, S.; Mrugalska, B.; Wyrwicka, M.; Souza, M.; Ávila, J.; Cayres, E.; Ávila, J.: Cognitive and Oganizational Criteria for Workstation Design. In: 10th International Conference on Applied HFs and Ergonomics (AHFE) and the Affiliated Conferences, Washington D.C. Conference Proceedings Springer; (2019).

${ }^{13}$ Ávila Filho, S., Rodrigues, Z., Kalid, R. A., Nascimento, V. Good practices in cooling towers: comparison between industrial audits. In: Cooling Technology Institute Annual Conference. Corpus Christi, Texas, 2013.

14 Ávila, S., Kiperstok, A., Braga, B., Kalid, R. Avoiding loss of energy in a petrochemical industry, operation and design. Energy Efficiency (EE). World Renewable Energy Congress, 2011 - Swede.

15 IEA, I. E. A. (2019). The Future of Hydrogen. In The Future of Hydrogen. https://doi.org/10.1787/1e0514c4-en

${ }^{16}$ Bakey, K. (2015). The Production of Hydrogen Gas: Steam Methane Reforming.

17 IRENA, I. R. E. A. (2019). Hydrogen: A renewable energy perspective. Tokyo Japan. 